(C) 1998 The Chemical Society of Japan

一総 合論文——

\title{
ソノエレクトロケミストリーの新展開 超音波照射場における有機電極反応一
}

(1997 年 11 月 28 日受理)

\author{
跡部真人·野中 勉*
}

\begin{abstract}
超音波の著しい作用効果を有機電極反応に反映させることを目的とし，様々な超音波照射電解反応系 を精査した．その結果，超音波照射により有機電極反応の高電流効率化ならびに/あるいは生成物選択 性の向上が達成されることが示された。 また，これらの超音波効果は主として電極反応に打ける物質移 動過程への影響が顕著であることが理論と実験により検証され, 特にキャビテーション現象がその主役 を演じることが明らかにされた，さらに，超音波照射下に拈ける電解重合反応では高密度重合膜の形成 が示された。これらの成果は, 有機電極反応の新しい制御手法としての超音波効果利用の第一歩として 意義づけられ，今後の多様な展開が期待される.
\end{abstract}

\section{1 はじめに}

超音波の化学反応に及ほす効果(化学効果), 特に電気化学反応 に及ほす効果(電気化学効果)に関する先駆的研究は日本人により 着手された．化学効果に関する最初の報告はWoodらにより 1927 年になされたが，現象観察にとどまっていた1).1933 年, 森口は一連の報告の第一報を本誌に投稿した 2)-4)，その内容は実 に示唆に富むむのであり, 特に固-液界面反応(金属や大理石の 酸への溶解)の速度が超音波により著しく增大するという今日の 超音波化学における基本的概念をすでに見いたしている．続いて 翌年には, 電極反応系に超音波を照射して, 濃度分極と過電圧に 対する超音波の著しい影響についてボルタンメトリーにより明ら かにした3)4. これは超音波の電気化学効果に関する研究, すな わちソノエレクトロケミストリーの世界最初の報告であった。

前述のように超音波の化学効果に関する研究は1920 年代後半 にスタートし, 未熟な点も依然残ってはいるものの, 今日までに 比較的多くの成果が蓄積され, 成書や総説もある ${ }^{5)-10)}$. 一方, 電気化学効果に関する研究のスタートはわずか 7 年達かったた けにもかかわらず，その後の進展は遅く，電気メッキへの利用を 除けば，満足な総説すらない11)-13)。しかし，ごく最近になって 電気分析・測定分野を中心に電解合成にまで及ぶ広い電気化学の 領域で超音波効果に関する研究が急伸を始めた ${ }^{14)-17) . ~}$

周知のように, 超音波は力学的エネルギーであり, 化学反応を 直接駆動するには不十分である. しかしながら化学反応の制御工 ネルギーとしては極めて特改に富んでおり,この観点に立てば, ソノエレクトロケミストリーの急伸はむしろ当然のことかむしれ ない.

東京工業大学大学院総合理工学研究科, 226-8502 横浜 市緑区長津田町 4259
著者らはかねてより, 制御エネルギーとしての超音波利用に着 目し, より精ちな制御が必要とされる有機電極反応への応用展開 を図るとともにその効果を検証してきた，本論文ではまず，有機 ・無機を問わず電極反応における超音波利用において，とりわけ 重要とされる電解装置の幾何学的形状の影響について述へ, つい で有機電極反応に打ける物質移動促進効果, 有機電解合成反応へ の応用，ならびに超音波効果の発現原理と機構の解明，さらには 電解重合反応への応用にも言及し，揭題のテーマにおける著者ら のこれまでの成果に新しい結果を加えて総合的に論及する.

\section{2 超音波電解槽装置の幾何学的形状の影響}

\section{1 超音波照射電極系}

最も簡便な超音波照射電解は水をはった超音波洗浄器中に電解 セルを置くことによって実施できる. 確かに超音波洗浄器の普及 は，超音波電気化学のみならず超音波化学の研究全般の発展に大 きく奇与したことには簃う余地のないところである. しかしなが ら, 超音波電気化学(ソノエレクトロケミストリー)に打ける反応 は固-液不均一反応系であり、その再現性, 制御性, 効率性など に打いて超音波洗浄器を用いる実験は精度的にも䓧めて不十分と 言わざるを得ない(5)14)18). Fig. 1 に超音波洗浄器内での電解槽な らびに作用電極の配置を，またTable 1 にベンズアルデヒドの還 元反応(Scheme 1)をモデルとしたときの電解結果を示した ${ }^{19}$ ).

このモデル反応では, Scheme 1 に示されるように二つの生成 物 (HD と HM) が得られるが, 超音波洗浄器内に電解槽を設置し て電解すると電流効率 $(\mathrm{HD}+\mathrm{HM}), \mathrm{HD}$ 生成選択率ともに無稂 汼，機械携汼の場合より大きくなる．次章で詳述するが、これは 基質の物質移動を促進するという超音波効果の大めである. しか しながら，この超音波効果は，電極面の向きよりもむしろ超音波 洗浄器内に打ける電解槽の位置に強く依存することが Table 1 か 
らわかる，言い換えるならば，洗浄器内の音場は，反射，干渉扩 よび减衰などにより複雑化して抢り，電解反応に反映される超音 波エネルギーは伝搬の指向性を失い，単に強度だによって反応

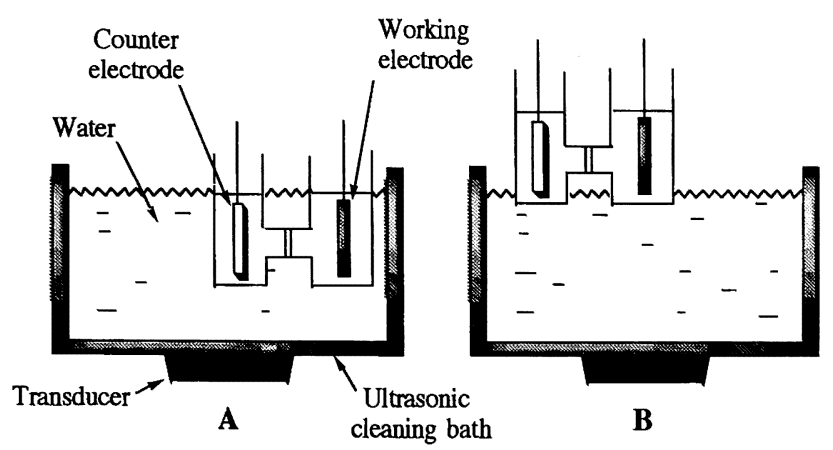

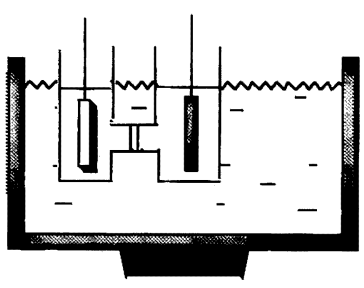

C

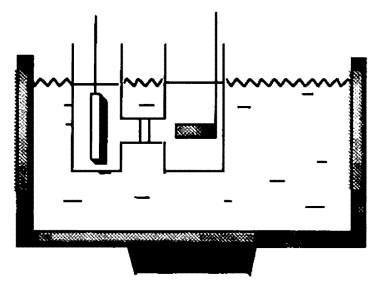

D
Fig. 1 Placement of cells and electrodes in an ultrasonic cleaning bath $(100 \mathrm{~W}, 36 \mathrm{kHz})$. Placement: The cell was well-immersed in the bath (A, C and D). Only the bottom of the cell was immersed in the bath (B). Working electrode chamber was placed in a corner $(\mathrm{A})$ and center (B, C and D) of the bath. Working electrode surface was positioned parallel (A, B and C) and perpendicularly (D) to the propagating direction of ultrasonic waves.

Table 1 Electroreduction of benzaldehyde ${ }^{\mathrm{a})}$ in an ultrasonic cleaning bath $(100 \mathrm{~W}, 36 \mathrm{kHz})$

\begin{tabular}{|c|c|c|}
\hline Stirring mode & $\begin{array}{l}\text { Current efficiency } \\
\text { for }[\mathrm{HD}]+[\mathrm{HM}] / \%\end{array}$ & $\begin{array}{l}\text { Product selectivity } \\
\text { for }[\mathrm{HD}] / \%\end{array}$ \\
\hline Still & 36 & 40 \\
\hline Mechanicalb) & 63 & 72 \\
\hline Ultrasonic $A^{c)}$ & 66 & 72 \\
\hline Ultrasonic $\mathrm{B}^{\mathrm{c})}$ & 70 & 96 \\
\hline Ultrasonic $\left.C^{c}\right)$ & 69 & 97 \\
\hline Ultrasonic $\mathrm{D}^{\mathrm{c})}$ & 70 & 96 \\
\hline
\end{tabular}

a) Electrolyzed by passing $0.5 \mathrm{~F} \mathrm{~mol}^{-1}$ at $20 \mathrm{~mA} \mathrm{~cm}^{-2}$ on a lead cathode in a $0.25 \mathrm{M} \mathrm{H}_{2} \mathrm{SO}_{4} / 50 \% \mathrm{MeOH}$ solution $\left(1 \mathrm{M}=1 \mathrm{~mol} \mathrm{~L}^{-1}\right)$. b) Stirred by a rotating magnet bar. c) See Fig. 1 .

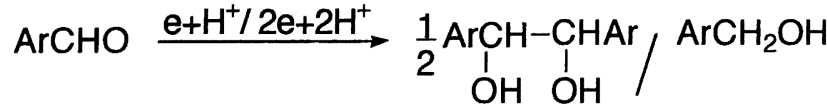

(HD)

Ar: $\mathrm{C}_{6} \mathrm{H}_{5}, p-\mathrm{CH}_{3} \mathrm{C}_{6} \mathrm{H}_{4}, p-\mathrm{CNC}_{6} \mathrm{H}_{4}$

Scheme 1 Electroreduction of benzaldehydes to the corresponding hydrodimeric (HD) and hydromonomeric (HM) products.
結果に影響を与えているものと考えられる．また，超音波洗浄器 内ならびに電解セル内の音場は, 洗浄器水位, セル底部の形状な

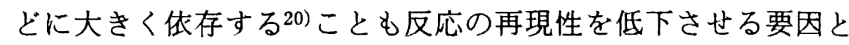
なっている. したがって, 高精度かつ高再現性の実験を行うため には, 音源からの超音波の伝搬指向性, 電極表面の距離や角度な どを十分精密に制御できる電解装置が不可欠である.

超音波振動子ステップホーンは超音波エネルギーの出力制御が 容易であり，また超音波発振源を直接反応系に導入することがで きるため反応の再現性ならびにエネルギーの効率性が高く，現在 のソノケミストリーに拀いて常用されつつある510). Fig. 2 に超 音波振動子ホーンを配した電解セルの概略図を，またTable 2 に p-メチルベンズアルデヒドの還元反応(Scheme 1)をモデルとし た電解結果を示す 19 ).

これらの結果から，超音波振動子ホーンは前述のように電解液 に直接振動源を漫漬させるため, 出力 $100 \mathrm{~W}$ の洗浄器による超 音波効果とほほ同等の効果を打よそ10 分の 1 の出力で達成でき

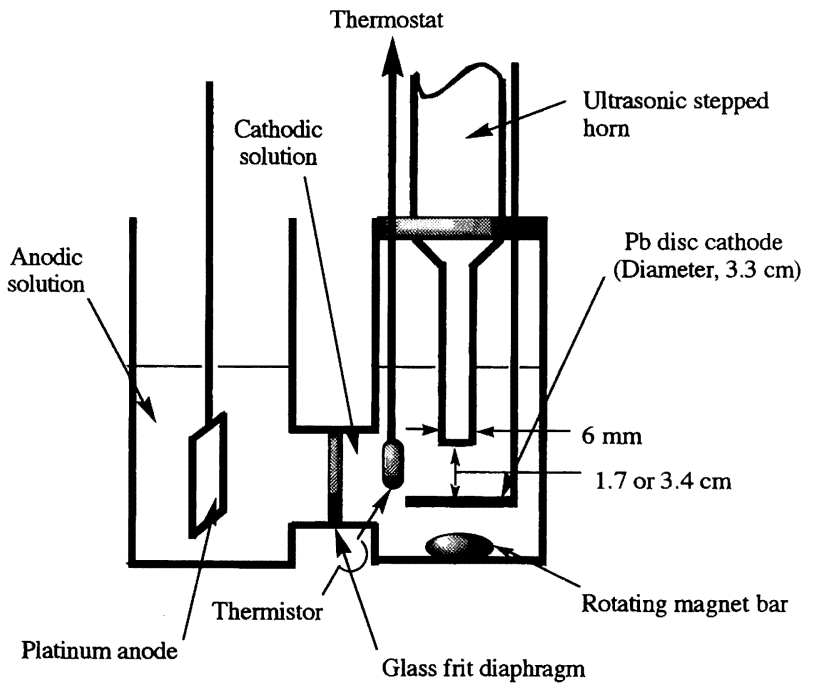

Fig. 2 Electrolytic cell with an ultrasonic horn (a titanium alloy rod with $6 \mathrm{~mm}$ diameter, $0-20 \mathrm{~W}, 20 \mathrm{kHz}$ ).

Table 2 Electroreduction of $p$-methylbenzaldehyde ${ }^{a}$ at various stirring/irradiation modes

\begin{tabular}{lcc}
\hline Stirring mode & $\begin{array}{c}\text { Current efficiency } \\
\text { for }[\mathrm{HD}]+[\mathrm{HM}] / \%\end{array}$ & $\begin{array}{c}\text { Product selectivity } \\
\text { for }[\mathrm{HD}] / \%\end{array}$ \\
\hline Still & 35 & 0 \\
Mechanical $^{\mathrm{b})}$ & 74 & 67 \\
Ultrasonic $^{\mathrm{c})}$ & 77 & 99 \\
Ultrasonic $^{\mathrm{d}, \mathrm{e})}$ & 72 & 93 \\
Ultrasonic $^{\mathrm{d}, \mathrm{f})}$ & 80 & 96 \\
Ultrasonic $^{\mathrm{d}, \mathrm{g})}$ & 89 & 98 \\
Ultrasonic $^{\mathrm{g}, \mathrm{h})}$ & 70 & 94 \\
\hline
\end{tabular}

a) Electrolyzed by passing $0.5 \mathrm{~F} \mathrm{~mol}^{-1}$ at $20 \mathrm{~mA} \mathrm{~cm}^{-2}$ on a lead cathode in a $0.25 \mathrm{M} \mathrm{H}_{2} \mathrm{SO}_{4} / 50 \% \mathrm{MeOH}$ solution. b) Stirred by a rotating magnet bar. c) Cathode was positioned $6 \mathrm{~cm}$ apart from the bottom of an ultrasonic cleaning bath $(100 \mathrm{~W}, 36 \mathrm{kHz})$.d) The cathode was positioned $1.7 \mathrm{~cm}$ apart from the top of an ultrasonic horn $(0.6 \mathrm{~cm}$ diameter, $20 \mathrm{kHz})$. e) Ultrasonic power, $4 \mathrm{~W} . \mathrm{f}) 8$ $\mathrm{W} . \mathrm{g}) 12 \mathrm{~W} . \mathrm{h}$ ) The cathode was positioned $3.4 \mathrm{~cm}$ apart from the top of the horn. 
ることがわかる．また電極反応の反応場は電極界面であるため, 超音波効果はホーンの先端と電極との距離に大きく依存するが, 距離を一定にさえすれば，出力強度に応じた超音波効果を再現で きることが明らかとなった。

このように電解液中に浸漬した超音波振動子ホーンを用いるこ とにより，超音波効果を再現性よく観測できるが，より精密な実 験を必要とする場合にはをたいくつかの問題が残る。たとえば, 超音波が反応系中に打いて定在波を形成すれば節と腹が生じるた め, 電極表面に達する波動が節部か腹部かによりその効果に差違 があるはずである.すなわち，常用される周波数数十 $\mathrm{kHz}$ の超 音波の水中に抢ける波長は数 $\mathrm{cm}$ であるから, 超音波振動子ホー ソと電極との距離が 4 分の 1 波長ごとに超音波効果が周期的に 変わることになる. もちろん超音波の到達エネルギーが音源から の距離に対し, 指数関数的に減少することによる複雑性があるに しても, 超音波効果の 4 分の 1 波長ごとの周期性は実際には不 明瞭であった．これは電解槽内壁面からの反射波が複雑に錯綜す るためであり, 理論上は定在波が形成されるような電解槽設計を 行えば解決される問題ではあるが, 実際的ではない，また，電極 表面位直における超音波エネルギー(音波強度)を直接計測するこ とができれば実験の精度を格段に高めることができるが，今のと ころ様々な手法や装置が開発されつつある段階であり, 精度, 実 用性のいずれからみても極めて不十分である. 後述するようにキ ヤビテーション計の使用により一定の成果が得られているが，限 られたものである．このため，ここで述へた超音波照射電極系で は, 反応セル, 電極, 超音波源の幾何学的形状 - 配㯰などの反応 装置の構成要素に細心の注意を払う必要があることが示唆され る.

\section{2 超音波振動(発振)電極系}

前節で述べた超音波照射電解では超音波源から電極に超音波が 照射されるが，反射，干渉，減衰などのため再現性が低く，精密
な制御が困難である，著者らはこの問題を克服するため，電極自 身が超音波振動する超音波振動(発振)電極を着想した。すなわ ち，電極自体を超音波振動させることにより，超音波が電解液中 を伝搬するために生起する諸問題を回避をたは極小化することを 試みた。つまり，この電極上に打ける超音波強度は伝搬中の减衰 を考虑する必要がないので, 発振体の出力そのむのと見なすこと ができる.しかし, 超音波の散乱による電解槽内壁面からの反射 や干渉の影響は絶無ではない.

超音波振動電極としては超音波振動子ホーン(チタン $90 \%$ ーア ルミニウム $6 \%$-バナジウム $4 \%$ 合金)自身を用い，その先端断 面 (Fig. 3(a)TSL 陰極)，側面の振動節部(Fig. 3(b)LN 陰極) と腹 部(Fig. 3(c)LL 陰極)の 3 箇所それぞれに打ける電極反応をベン ズアルデヒド類の陰極還元をモデル(Scheme 1) として検討した (Fig. 4, 5 および 6) ${ }^{21) 22) . ~}$

その結果，いずれの電極においても出力強度の増加に伴い, 全 電流効率 $(\mathrm{HD}+\mathrm{HM})$ ならびに HD 生成選択率が增大するという 超音波照射型と同様の作用効果を示すことが明らかとなった.

しかしながら，超音波振動子ホーンの側面部(LN, LL 陰極)を 電極とした場合においては, ホーンの先端をセプタムキャップに より超音波遮へいしているため, 電解液への超音波の伝搬がない にもかかわらず，上記のように超音波効果が発現し，また，腹部 (LL 陰極)においてその作用効果が大きいことは大変興味深く, 先端断面電極あるいは照射型の電極(いずれもキャビテーション 現象による超音波効果) とはその機作を異にしていることが考え られる.これは超音波振動子ホーン(ステップホーン)自身の振動 分布 (Fig. 7) に基づいた考察, すなわち, 腹側の振動変位ならび に速度変位が節側よりも大きいため, 腹部電極(電極界面に対し, 平行に振動している)に接した電解液（静止していると仮定）の電 極に対する相対流速が節部のものより速くなることに起因してい るとして説明される。

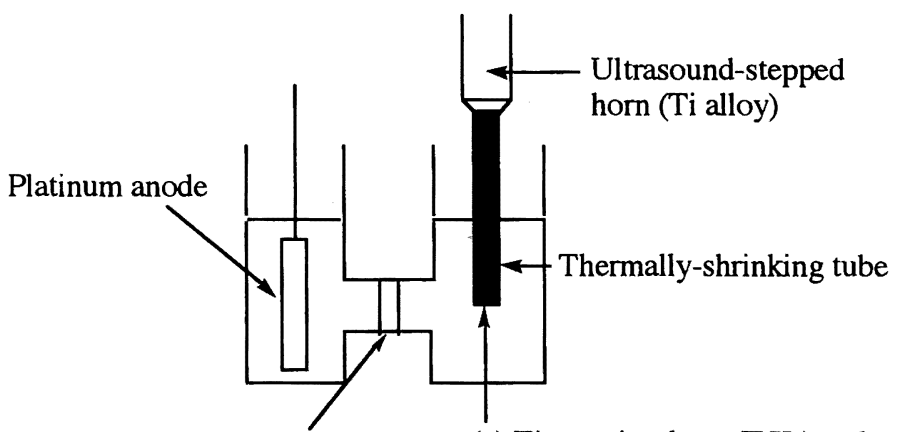

$\mathrm{H}$-shaped divided cell

(a) Tip-section-loop (TSL) cathode

(Diameter : $19 \mathrm{~mm}$, Area : $2.8 \mathrm{~cm}^{2}$ )

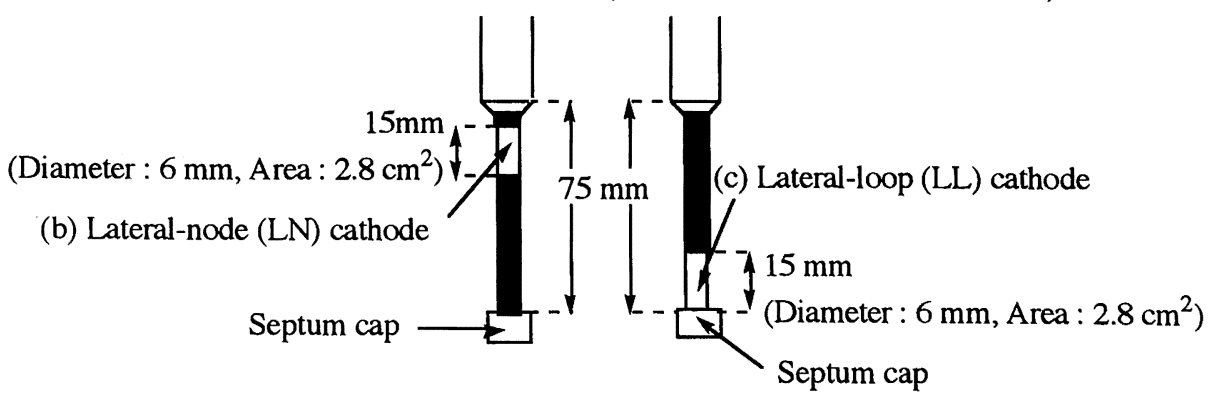

Fig. 3 Ultrasound-vibrating electrodes. 


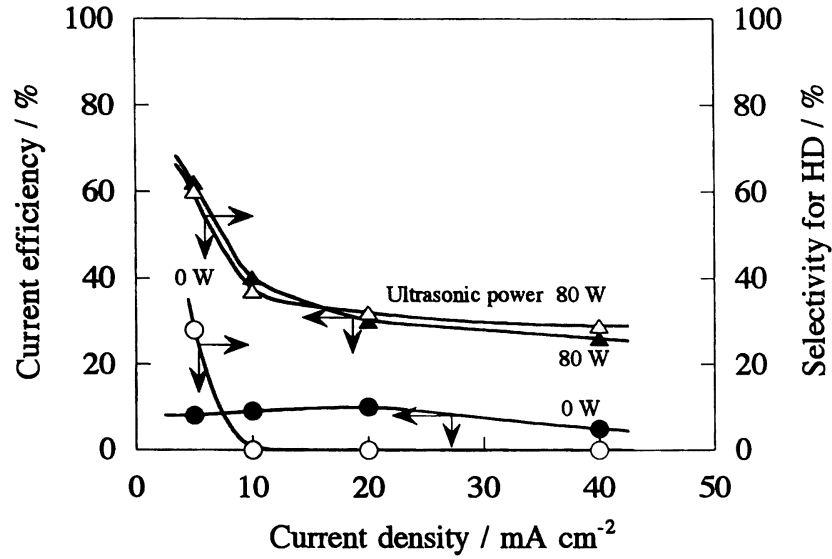

Fig. 4 Electroreduction of 4-cyanobenzaldehyde on the tip-section-loop (TSL) cathode of an ultrasoundstepped horn $(20 \mathrm{kHz})$. Current efficiency for HM + HD: $0 \mathrm{~W}(\mathbf{O}), 80 \mathrm{~W}(\mathbf{\Delta})$. Selectivity for HD: 0 $\mathrm{W}(\mathrm{O}), 80 \mathrm{~W}(\triangle)$.

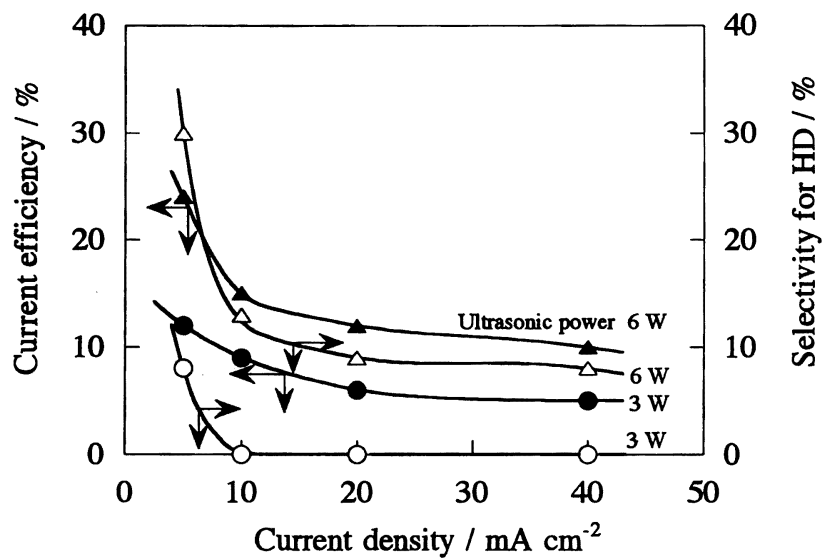

Fig. 5 Electroreduction of 4-cyanobenzaldehyde on the lateral-node (LN) cathode of an ultrasound-stepped horn $(20 \mathrm{kHz})$. Current efficiency for $\mathrm{HM}+\mathrm{HD}: 3 \mathrm{~W}$ (O), $6 \mathrm{~W}$ (ム). Selectivity for HD: $3 \mathrm{~W}(\bigcirc), 6 \mathrm{~W}$ $(\triangle)$.

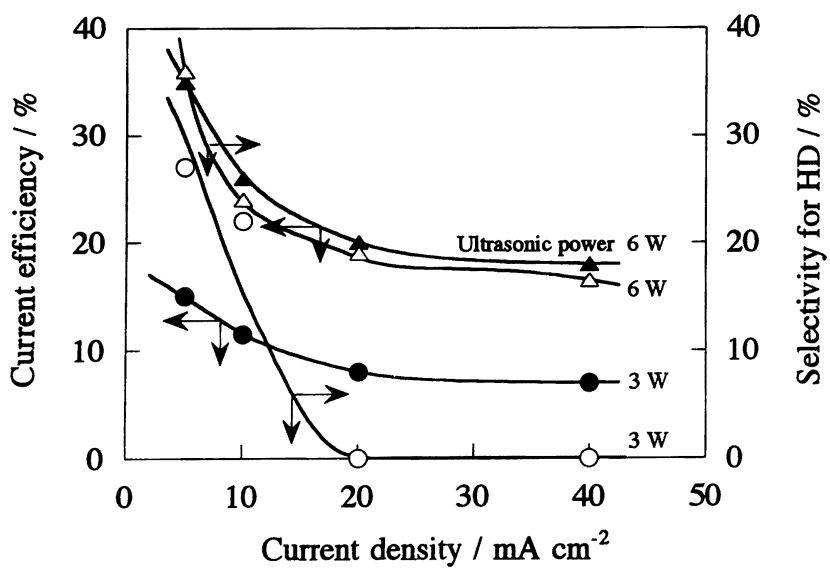

Fig. 6 Electroreduction of 4-cyanobenzaldehyde on the lateral-loop (LL) cathode of an ultrasound-stepped horn $(20 \mathrm{kHz})$. Current efficiency for $\mathrm{HM}+\mathrm{HD}: 3 \mathrm{~W}$

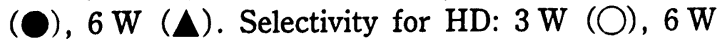
$(\triangle)$.

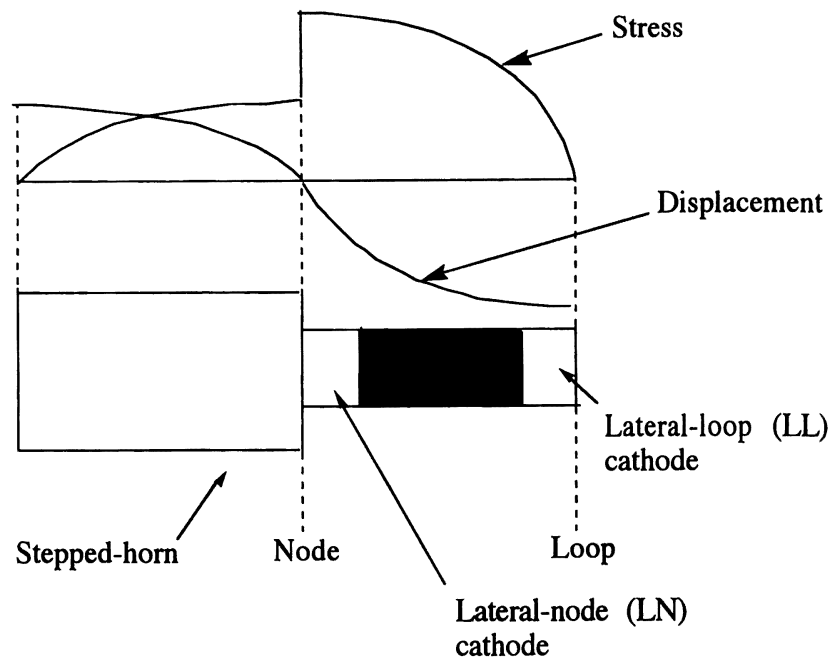

Fig. 7 Distribution of vibration in an ultrasound-stepped horn

また，超音波振動電極では電極と超音波源の距離を考虑する必 要がないことから反応の再現性, 制御性においては有利である が，振動子ホーンと異なる材質の電極の場合にはホーンへの接合 方法に工夫を要する.

\section{3 有機電極反応における物質移動促進効果}

\section{1 ボルタンメトリーによる超音波効果の評価}

マクロスケールの電解反応に対する超音波による反応促進すな わち高効率化は，電流効率や収率の増加等によって示されるが， 電気化学測定では上記の反応促進効果が電流密度の増大などの別 の側面から観察される.このため, 電気化学測定, 特にボルタン メトリーにより電極反応の超音波効果を評価する研究は, 有機, 無機を問わずかなり多くの報告がされており, 現在ではソノエレ クトロケミストリーにおけるーつの研究分野を形成しつつあ る23)-29). 著者らは, 前述の酸性溶液中に打ける アルデヒドの還元に対して, 定常法によるボルタンメトリー測定 を行い, 超音波効果を解析した(Fig. 8) ${ }^{19) 30) . こ の ホ ゙ ル タ ン モ ク ゙ ~}$ ラムより，機械摫拌下ならびに超音波照射下のいずれの場合にお いても飽和電流(払散限界電流)が得られており，この電流値は機 械摫汼より超音波照射下で，さらには超音波出力が大きいほど増 加する.この超音波効果は物質移動促進に起因していると推察さ れ，次節で述べる理論的な解析により，たとえば， $10 \mathrm{~W}$ 前後の 出力強度下における拡散限界電流値は, 回転電極に打ける数千 $\mathrm{rpm}$ の回転数, またフローセルにおいては数十 $\mathrm{m} / \mathrm{min}$ の流速と いう技術的には実用がかなり困難な条件で得られる值に相当する ことも明らかとなった ${ }^{31)-35)}$.

\section{2 シミュレーションによる超音波効果の理論的解析}

芳香族アルデヒド類の電解還元を超音波照射下で行うことによ り，還元二量体(HD)の生成が著しく促進されることを2.1に打 いて述べた。 また，3.1ではボルタンメトリー測定の結果から， この電解還元反応に及ほす超音波効果が物質移動促進に起因して いることが示唆された，本節においては物質移動現象を考虑に入 れ，シミュレーションにより超音波効果を理論的に解析する. 酸 性水溶液中での芳香族アルデヒド類の電解還元に打ける還元二量 


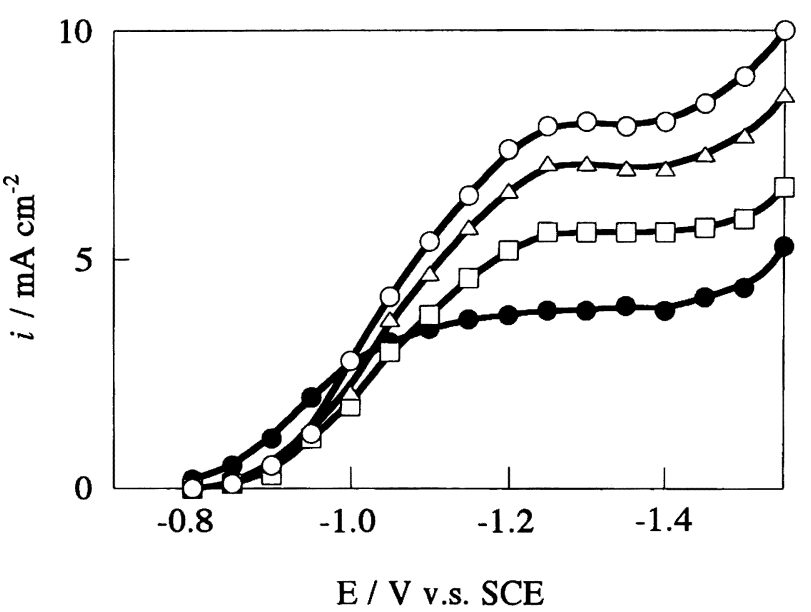

Fig. 8 i-E curves for $p$-methylbenzaldehyde at a lead cathode in $\mathrm{H}_{2} \mathrm{SO}_{4} / 50 \% \mathrm{MeOH}$ under ultrasonic irradiation with various powers. Ultrasonic power: $0 \mathrm{~W}$ (Mechanically stirred) (O), $4 \mathrm{~W}(\square), 8 \mathrm{~W}(\triangle), 12$ $\mathrm{W}(\mathrm{O})$.

体(HD) と還元単量体(HM)の生成比(生成物選択率)については, 定説化された反応機構(Scheme 2)に基づて物質移動係数を用 いた数学的な解析がなされている31)-35).

Scheme 2 において，アルデヒド種の電極界面への物質移動釈 数を $m$, 濃度を $C$ とすれば( 1 )式が与えられる.

$$
\frac{V \mathrm{~d} C}{A \mathrm{~d} t}=-\frac{i_{\mathrm{L}}}{F}=-m C
$$

ここで， $V, A, t, i_{\mathrm{L}}$ および $F$ はそれぞれ，電解液容積，電極表面 積, 電解時間, 1 電子還元の拡散限界電流密度およびファラデー 定数である. 一方, 3.19 Fig. 8 における拡散限界電流密度 $\left(i_{\mathrm{L}}\right)$ から，（1）式を用いて各超音波強度における物質移動係数 $m$ を 求めることができる(Table 3$)$.

\section{Cathode}

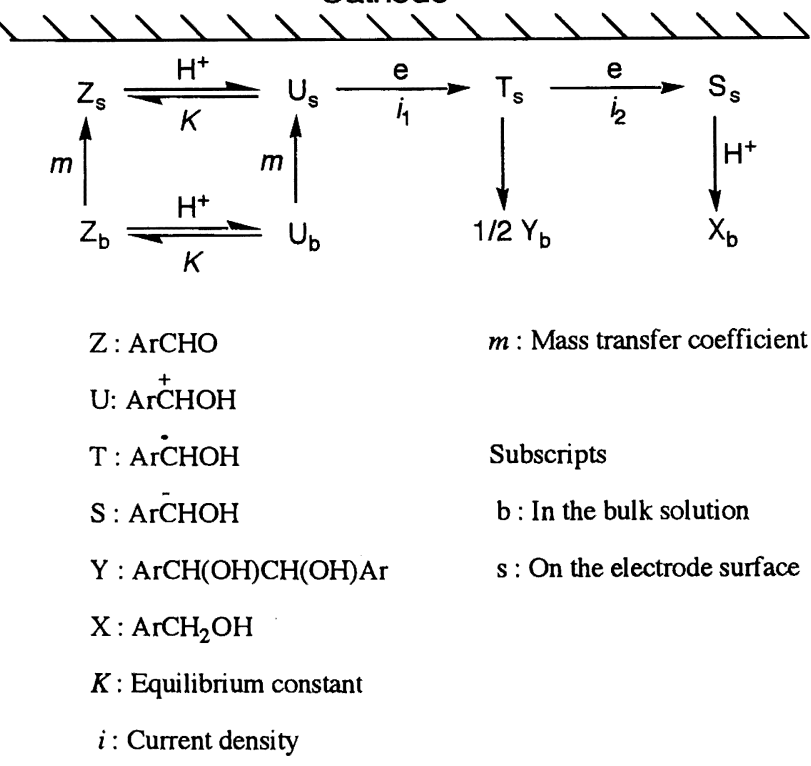

Scheme 2 Mechanistic reaction scheme for the reduction of $p$-methylbenzaldehyde in an acidic solution.
Table 3 Mass transfer coefficients $(m)$ for $p$-methylbenzaldehyde estimated from limiting currents $\left(i_{L}\right)$ under ultrasonic irradiation ${ }^{\text {a }}$

\begin{tabular}{cc}
\hline Ultrasonic power $/ \mathrm{W}$ & $m / 10^{-3} \mathrm{~cm} \mathrm{~s}^{-1}$ \\
\hline $0^{\mathrm{b})}$ & 3.9 \\
4 & 5.5 \\
8 & 7.0 \\
12 & 8.0
\end{tabular}

a) The cathode was positioned $1.7 \mathrm{~cm}$ apart from the top of an ultrasonic horn $(0.6 \mathrm{~cm}$ diameter, $20 \mathrm{kHz})$. b) Mechanically stirred.

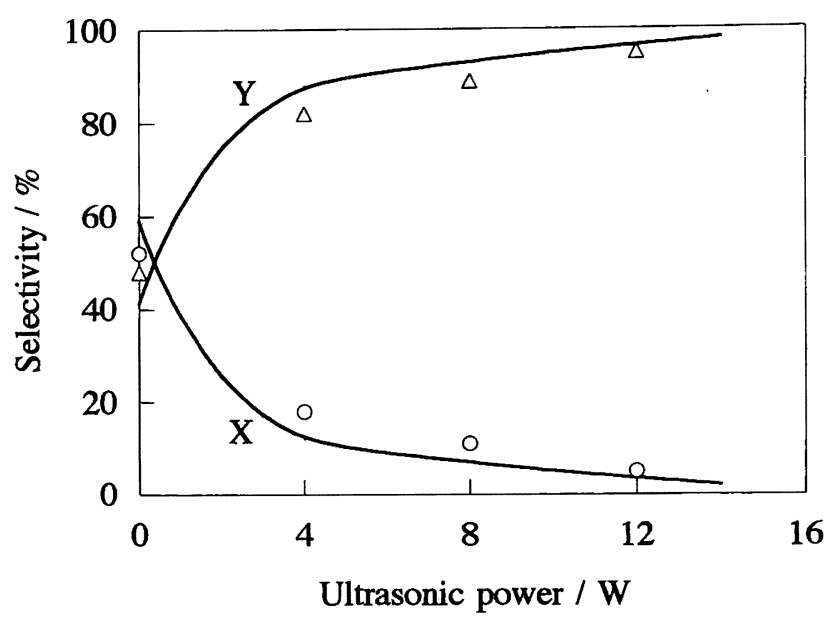

Fig. 9 Product-selectivities calculated (curves) and experimentally obtained (plots) for 4,4'-dimethylhydrobenzoin (Y) and $p$-methylbenzyl alcohol (X) in the $p$-methylbenzaldehyde reduction. Selectivity for $\mathrm{X}$ $(\bigcirc)$ and $Y(\triangle)$.

数学式の誘導の手順は省略するが，この $m$ の値を用いて $(1)$ 式を解くことにより（2）および( 3 )式で定義される生成物選択 率が算出される。

Selectivity for $\mathrm{Y}=\frac{\Delta[\mathrm{Y}]}{\Delta[\mathrm{X}]+\Delta[\mathrm{Y}]} \times 100[\%]$

Selectivity for $\mathrm{X}=\frac{\Delta[\mathrm{X}]}{\Delta[\mathrm{X}]+\Delta[\mathrm{Y}]} \times 100[\%]$

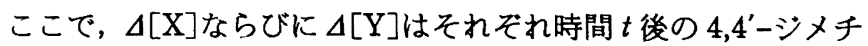
ルヒドロベンゾイン $(\mathrm{X})$ とp-メチルベンジルアルコール $(\mathrm{Y})$ の生 成量である．このような手順により，ある特定の電解条件下にお ける生成物選択率をシミュレーションした結果が Fig. 9 の実線 で与えられる. また, Fig. 9 のブロットは実際にマクロスケール の電解反応を行った場合の実験值であるが，超音波の物質移動の 促進効果を前提とした理論曲線との良い一致が認められた.この ことにより，有機電極反応に打ける超音波効果の一つとして，物 質移動促進が理論的にも検証され，また生成物選択率が超音波出 力で制御しうることも明らかにされた.

\section{4 有機電解合成への応用}

有機電解合成はクリーンな化学合成工程として評価され， 1960 年代以降, 膨大な基礎研究の知見が蓄積されてきたが，実 
用化は必ずしも順調ではなかった．その一般的(普遍的)原因は， 水電解液の使用が工業的に不可避であるにむかかわらず水自体の 奄解による酸素・水素発生を抑制できず電解反応の電流効率が低 いこと，目的生成物の選択性の制御が難しいこと，また電解電流 密度 (反応速度)が低いことなど技術上致命的な問題を解決するた めの工学基礎の未熟にあった。しかしながら，これらの難問は前 述の超音波効果利用により，十分解決できるむのと思われる.す なわち，超音波による物質移動促進により，電流効率向上，電流 密度 (反応速度)の增大, さらには生成物選択性の制御においても 超音波が一定の寄与をしうることが期待できるからである．ここ では，超音波効果を応用した様々な有機電解合成反応を以下に示 す.

\section{1 通常電枉系}

以下に掲げるマレイン酸エステル，ハロゲン化ベンジルならび

\section{$\mathrm{CH}_{2} \mathrm{COOCH}_{3}$}

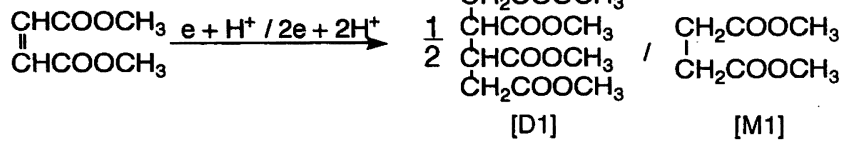

$\mathrm{PhCH}_{2} \mathrm{Br} \stackrel{\mathrm{e}+\mathrm{H}^{+} / 2 \mathrm{e}+2 \mathrm{H}^{+}}{\longrightarrow} \frac{1}{2} \mathrm{PhCH}_{2} \mathrm{CH}_{2} \mathrm{Ph} / \mathrm{PhCH}_{3}$

[D2] [M2]

$\mathrm{PhCOOH} \stackrel{2 \mathrm{e}+2 \mathrm{H}^{+} / 4 \mathrm{e}+4 \mathrm{H}^{+}}{\longrightarrow} \mathrm{PhCHO} / \mathrm{PhCH}_{2} \mathrm{OH}$

$$
\text { [M3] [M4] }
$$

Scheme 3 Electroreduction of dimethyl maleate, benzyl bromide and benzoic acid.
に安息香酸の電解還元反応は，いずれも有機電解合成における基 本的な反応である (Scheme 3)，これらの電解反応を基質との電 子移動を媒介する通常の電極を用いて2.1の超音波照射電極系で 行った場合の超音波効果を合成化学的観点から検討した。

Table 4 に示されるように, これらの反応においても機械摜汼 では達成し得ない超音波による生成物選択率ないし電流効率への 著しい作用効果が認められた，とりわけ，安息香酸の電解還元反 応に抢ける超音波効果は著しく，超音波出力に対する生成物選択 率のシミュレーションによる值と実験值との一致も検証された が，詳細は省略する ${ }^{19) 28) . ~}$

\section{2 反応性電極系}

4.19電解系は電叒が反応基質分子との電子移動媒体として作 動するいわゆる通常の電極反応であり，またほとんどの電極反応 はこれに属するものである.これに対し，事例が少ないとはい え, 電極材料自身が化学量論的に反応に参与する反応性電極の反 応は有機金属化合物の合成に用いられている36)37)。このような 反応性電極系に颃いても超音波の影響は著しく，その作用効果は 実に興味深いものがある.

例えば，反応性スズ陰極上でのヨウ化メチルの電解還元反応 (Scheme 4) を超音波照射を含む種々の反応モードにおいて行っ たところ，超音波照射下ではスタンナン $\left(\mathrm{Me}_{4} \mathrm{Sn}\right)$ の生成が抑制 され，シスタンナン $\left(\mathrm{Me}_{3} \mathrm{SnSnMe}\right.$ ) の生成が促進されることが 明らかとなった(Table 5) ${ }^{38) 39) . ~}$

ジスタンナンの生成は Scheme 4 に示すように，陰極表面を胁 散するトリメチルスタンニルラジカル $\left(\mathrm{Me}_{3} \mathrm{Sn} \cdot\right)$ のホモカッフ リングによると考えられており40)-44)，上記の超音波効果は陰極

Table 4 Electroreduction of dimethyl maleate, benzyl bromide and benzoic acid

\begin{tabular}{|c|c|c|c|}
\hline Starting compound & Stirring mode & $\begin{array}{c}\text { Current efficiency for }[\mathrm{D} 1]+[\mathrm{M} 1],[\mathrm{D} 2]+[\mathrm{M} 2] \\
\text { or }[\mathrm{M} 3]+[\mathrm{M} 4] / \%\end{array}$ & $\begin{array}{c}\text { Selectivity }[\mathrm{D} 1] /[\mathrm{M} 1],[\mathrm{D} 2] /[\mathrm{M} 2] \\
\text { or }[\mathrm{M} 3] /[\mathrm{M} 4]\end{array}$ \\
\hline Dimethyl maleate $^{\text {a) }}$ & Mechanical ${ }^{b)}$ & 93 & 0.3 \\
\hline Benzyl bromide ${ }^{d)}$ & Still & 40 & 0.0 \\
\hline Benzyl bromide ${ }^{d)}$ & Mechanical' ${ }^{\text {b) }}$ & 40 & 0.3 \\
\hline Benzyl bromide ${ }^{d)}$ & Ultrasonic c) & 40 & 0.9 \\
\hline Benzoic acide) & Mechanical'b) & 17 & 0.2 \\
\hline Benzoic acide) & Ultrasonic ${ }^{c)}$ & 54 & 1.5 \\
\hline
\end{tabular}

a) Electrolyzed at a lead cathode in a $0.025 \mathrm{M} \mathrm{KH}_{2} \mathrm{PO}_{4} / 0.025 \mathrm{M} \mathrm{Na}_{2} \mathrm{HPO}_{4} / 0.5 \mathrm{M} \mathrm{NaCl}$ solution. b) Stirred by a rotating magnet bar. c) The cathode was positioned $1.7 \mathrm{~cm}$ apart from the top of an ultrasonic horn $(0.6 \mathrm{~cm}$ diameter, $12 \mathrm{~W}, 20 \mathrm{kHz})$. d) Electrolyzed at a lead cathode in a methanolic $0.5 \mathrm{M}\left(\mathrm{C}_{2} \mathrm{H}_{5}\right)_{4} \mathrm{NBr}$ solution. e) Electrolyzed at a lead cathode in a $0.05 \mathrm{M} \mathrm{H}_{2} \mathrm{SO}_{4} / 0.2 \mathrm{M}$ citric acid solution.

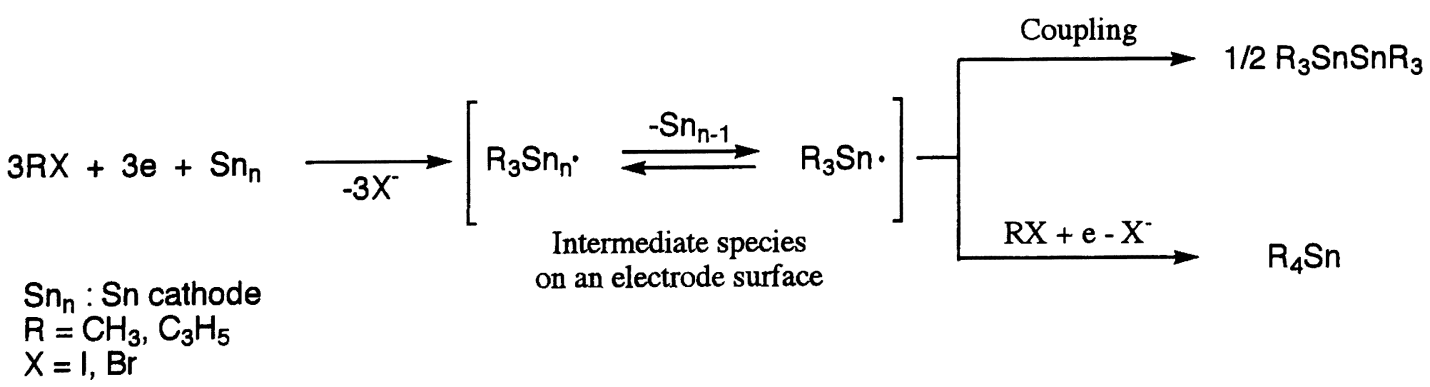

Scheme 4 Electroreduction of alkyl halides to the corresponding alkylstannanes at a reactive tin cathode. 
Table 5 Current efficiency and product selectivity $\left[\left(\mathrm{CH}_{3}\right)_{3}\right.$ $\left.\mathrm{SnSn}\left(\mathrm{CH}_{3}\right)_{3} /\left(\mathrm{CH}_{3}\right)_{4} \mathrm{Sn}\right]$ in the electroreduction of methyl iodide at a reactive tin cathode $\mathrm{c}^{\mathrm{a})}$

\begin{tabular}{lccc}
\hline \multirow{2}{*}{ Stirring mode } & \multicolumn{3}{c}{ Current efficiency/\% } \\
\cline { 2 - 4 } & $\mathrm{SnMe}_{4}$ & $\mathrm{Me}_{3} \mathrm{SnSnMe}_{3}$ & Total \\
\hline Still & 37 & tr. & 37 \\
Mechanical $^{\mathrm{b})}$ & 30 & 0 & 30 \\
Ultrasonic $^{\mathrm{c})}$ & 28 & 8 & 36 \\
Ultrasonic $^{\mathrm{c})}$ & 22 & 9 & 31 \\
+Mechanical $^{\mathrm{b})}$ & &
\end{tabular}

a) Electrolyzed in a non-aqueous $0.25 \mathrm{M} \mathrm{Bu}_{4} \mathrm{NClO}_{4} / \mathrm{DMF}$ solution. b) Stirred by a rotating magnet bar. c) The cathode was positioned $1.0 \mathrm{~cm}$ apart from the top of an ultrasonic horn $(0.6 \mathrm{~cm}$ diameter, $17 \mathrm{~W}, 20 \mathrm{kHz}$ ).

表面上に生成するこのラジカル中間種の表面拡散を超音波が促進 することに起因しているためと説明される.

また，酢酸水溶液中での銅陽極の電解酸化溶解反応による酷酸 銅の生成をモデルとした反応性陽極反応系(Scheme 5)に打いて は，超音波の著しい攪䢁作用による銅陽極の溶解促進により酢酸 銅の生成電流効率が著しく增大することが明らかとなった(Fig. 10) ${ }^{45)}$.

このように反応性電極系においても超音波効果を利用すること で，反応の高効率化あるいは生成物選択性の制御効果が達成され る.

\section{3 クロスカップリング反応における超音波効果}

有機電極反応の一つの特徵的反応として, 酸化的あるいは還元 的炭素-炭素結合形成反応，いわゆる 2 分子カップリング反応が ある．例えば，陽極反応では Kolbe 電解，陰極反応では前述の カルボニル化合物の還元によるピナコール体の生成などがその典 型的なものとして挙げられる.このようなカッブリング反応は同 一反応体基質についてたけではなく，二つの異なった反応体基質 間についても起こり，クロスカップリング反応として合成化学的 に有用性が高い46). しかし，ホモカッブリング反応との競合の ためクロスカッブリング生成物の選択性を高めることは一般に容 易ではない.

そこで，著者らは超音波効果を利用して，クロスカップリング

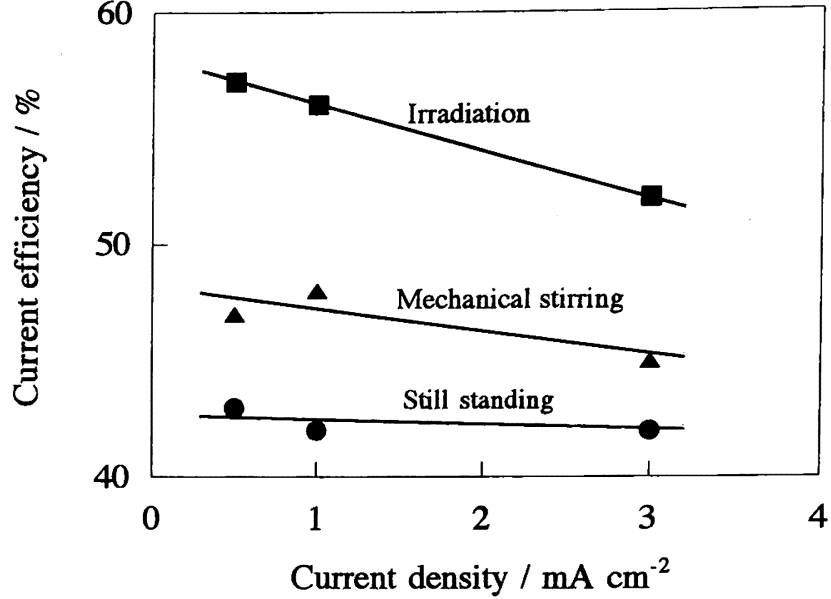

Fig. 10 Current efficiency for the formation of copper(II) acetate at a copper anode in an acetic acid solution at various current densities with $(\boldsymbol{D})$ and without $(\boldsymbol{\Delta}$ Mechanically stirring, $\mathbf{O}$ : Still standing) ultrasonic irradiation.

生成物を高選択的に得ることを着想し，アセトンーアクリロニト リルの陰極クロスカッブリング反応(Scheme 6) をモデル反応と した検証を行った。

Scheme 6 の反応では，アクリロニトリルはアセトン還元によ り生じるラシカルル間種の捕捉剤として機能するので, アクリロ ニトリル自体の直接還元を抑制するためにはアクリロニトリル湜 度をアセトンに対して相対的に低くする必要がある。このため, 電極近傍に㧤いて効率的にクロスカップリング反応を進行させる には，捕捉阂であるアクリロニトリルの物質移動を促進すること が必要となるが，超音波による物質移動促進効果を利用すること でクロスカップリング体(CD)の選択率は静置下，機械摜䢁下に 比べ飛躍的に高くなることが示された (Table 6) ${ }^{47)}$.

\section{4 間接電解反応における弨音波効果}

レドックスメディエーターによる間接電解の反応速度は, メデ ィエーター分子の触媒能(電子移動能)たけでは律せられず，電解 液中のメディエーターの電極表面への物質移動(拡散)によっても 支配される.

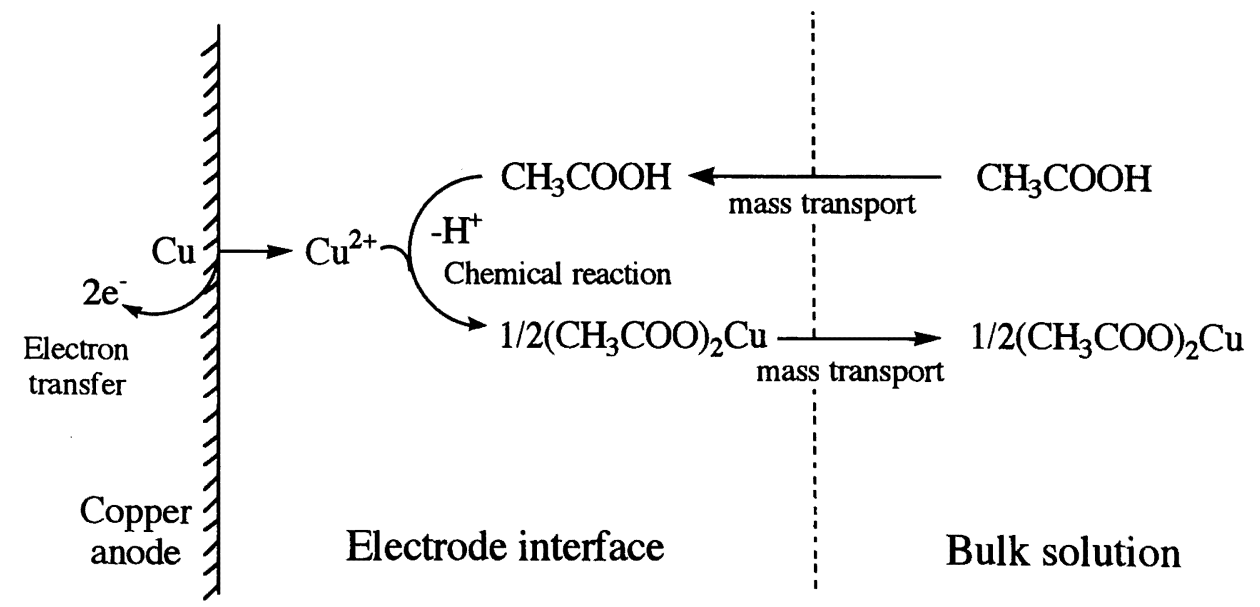

Scheme 5 Anodic dissolution of a copper electrode in acetic acid. 
<smiles>CC(C)=[C+][C+]=C[C@@H](C)OC(C)(C)O</smiles>

Pinacol
$\mathrm{H}_{3} \mathrm{C}$

$\mathrm{H}_{3} \mathrm{C}^{\prime} \mathrm{O}$

Cross-coupling product<smiles>CC</smiles><smiles>[CH]O</smiles><smiles>CC</smiles>

\section{2-Propanol}

Scheme 6 Electroreduction of acetone in the presence of acrylonitrile in acidic media.

Table 6 Current efficiency and product selectivity for the cathodic crossed-coupling of acetone $(10 \mathrm{M})$ with acrylonitrile $(0.01 \mathrm{M})^{\mathrm{a})}$

\begin{tabular}{lcc}
\hline Stirring mode & $\begin{array}{c}\text { Current efficiency } \\
\text { for reduction/\% }\end{array}$ & $\begin{array}{c}\text { Selectivity for } \\
\text { cross-coupling/\% }\end{array}$ \\
\hline Still & 33 & 21 \\
Mechanical $^{\text {b) }}$ & 41 & 29 \\
Ultrasonic $^{\text {) }}$ & 41 & 59 \\
\hline
\end{tabular}

a) Electrolyzed at a lead cathode in a $2.8 \mathrm{M} \mathrm{H}_{2} \mathrm{SO}_{4}$ solution. b) Stirred by a propeller $(1000 \mathrm{rpm})$.c) The cathode was positioned $3.0 \mathrm{~cm}$ apart from the top of an ultrasonic horn $(1.9 \mathrm{~cm}$ diameter, $17 \mathrm{~W}, 20 \mathrm{kHz}$ ).

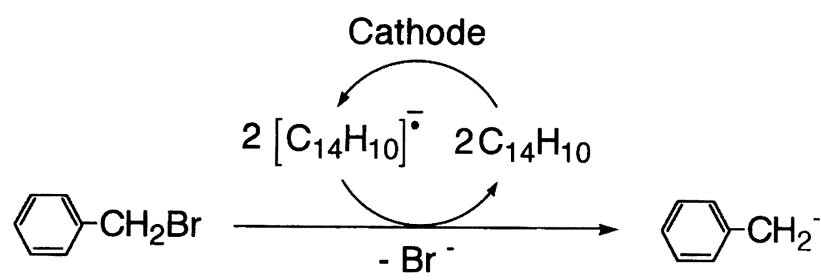

Scheme 7 The indirect reduction of benzyl bromide by a radical anion mediator electrogenerated from anthracene.

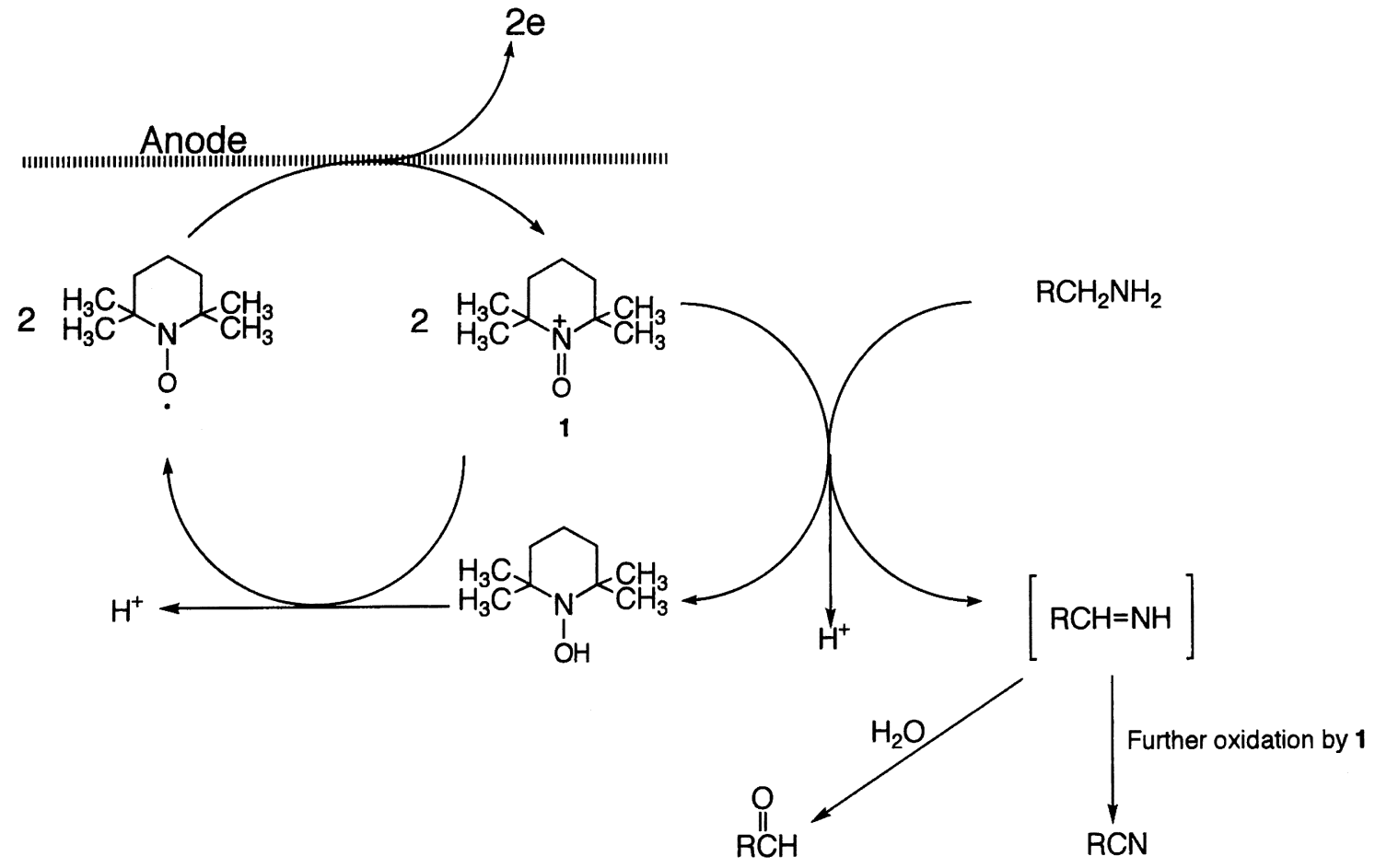

Scheme 8 The indirect oxidation of amines by a cation mediator electrogenerated from 2,2,6,6-tetramethylpiperidyl oxide (TEMPO). 


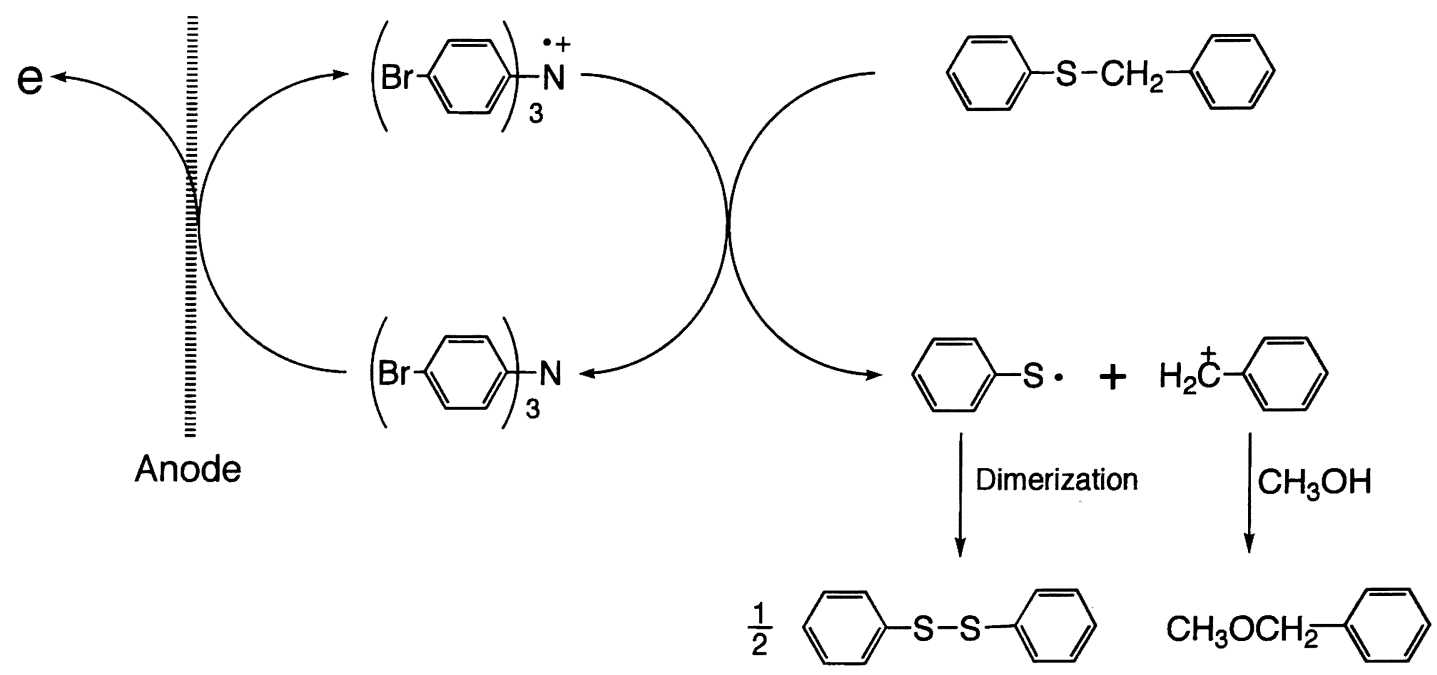

Scheme 9 The indirect oxidation of benzyl phenyl sulfide by a radical cation mediator electrogenerated from tris ( $p$-bromophenyl) amine.

そこで著者らは間接電解反応系に超音波を照射すれば，電極反 応速度は物質移動律速から解放され，本来のメディエーター分子 の有する電子移動触媒能が十分に発揮され得ると着想し，この原 理の妥当性を検証した.

その結果, アントラセンメディエーターによるベンジルブロミ ド僄元 (Scheme 7), 2,2,6,6-テトラメチルピペリシニルオキシド (TEMPO)メディエーターによるアミン類の酸化反応(Scheme 8)ならびにトリス(p-ブロモフェニル)アミンメディエーターに よるベンジルフェニルスルフィドの酸化反応 (Scheme 9) 等に拉 いて，例外なく反応速度の著しい増加(5-10 倍)認められた48).

\section{5 物質移動促進効果の発現原理と機構の解明}

超音波による物質移動促進がボルタンメトリーの電流値あるい は有機電解合成に抢ける収率や生成物選択性などに対し，極めて 著しい影響を与えることは上述のとおりである.ところが，この 物質移動促進のメカニズムが超音波のいかなる物理作用によるの かは，ここ数年来キャビテーションの生起が必須的要件か否かで 統一された見解が得られて抢らず不明確であった. キャビテーシ ヨンとは，粗密波である超音波の低圧部が液体の分子間力を上回 るほど十分に陰圧になったときに小さなバブル(空洞)を生じ，こ れが膨張と王縮の繰り返しののちに崩壊する現象であり，その崩 壊に際しては，局所的に数千度・数百一千気圧という極限状態， さらには超高速流を生ずるものである，最近，Klima らがキャビ テーションバブルのサイズレベルと同程度のマイクロ電極上に拝 いて超高速電位掃引する手法により，個々のキャビテーションシ エット流による電解電流の增加を直接的に測定することに成功し た49)50)

これに対し，著者らは電解系においてキャビテーションが生起 しているか否か，またキャビテーションによってのみ著しい物質 移動促進効果が発現されるかどうからいてキャビテーション計 を用いて検討し，超音波による物質移動制御のための技術的原理 を解明し，キャビテーション生起と物質移動速度増加の定量的関 係を明らかにした ${ }^{51) 52)}$. Fig. 11 はp-メチルベンズアルデヒドの 電解還元反応系に打ける超音波照射出力とキャビテーション計の

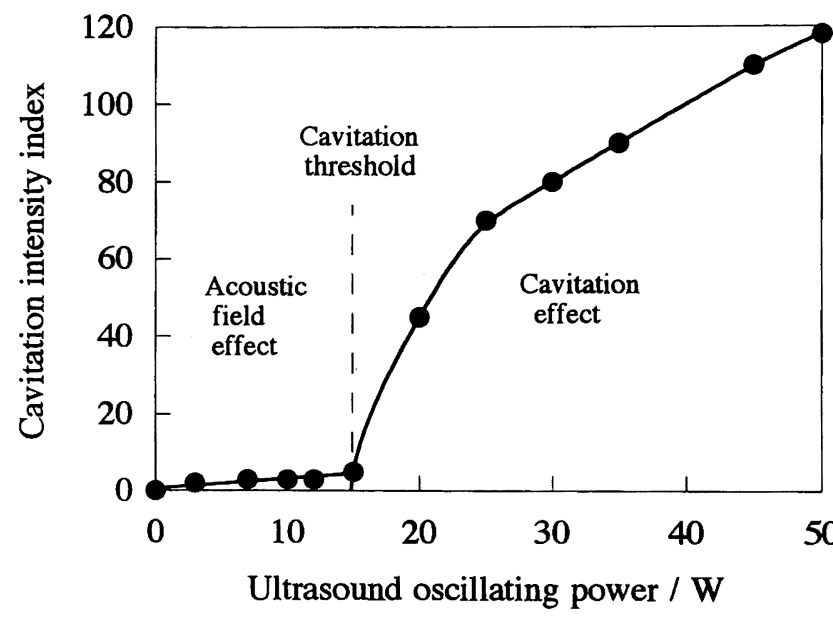

Fig. 11 Relationship between cavitation intensity index and ultrasound oscillating power in a catholyte for the reduction of $p$-methylbenzaldehyde.

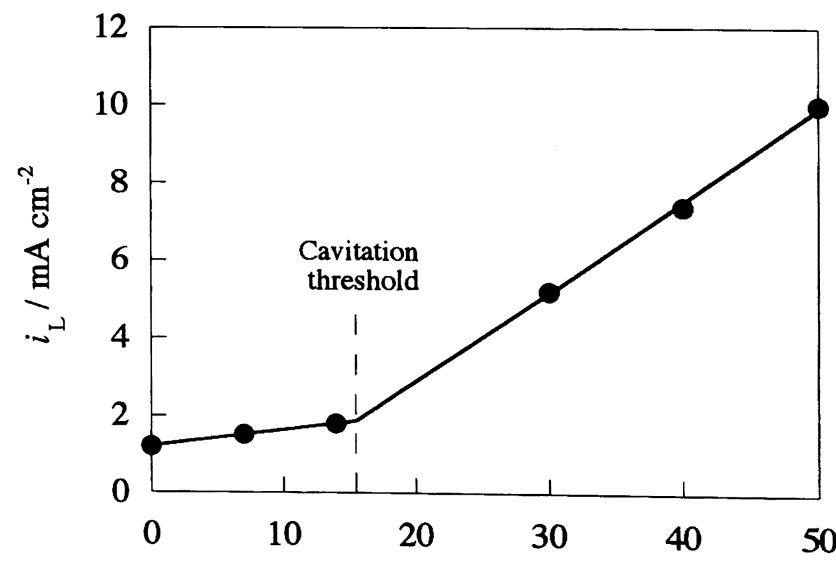

Ultrasound oscillating power / W

Fig. 12 Relationship between limiting current density $\left(i_{\mathrm{L}}\right)$ and ultrasound oscillating power in the reduction of $p$-methylbenzaldehyde. 

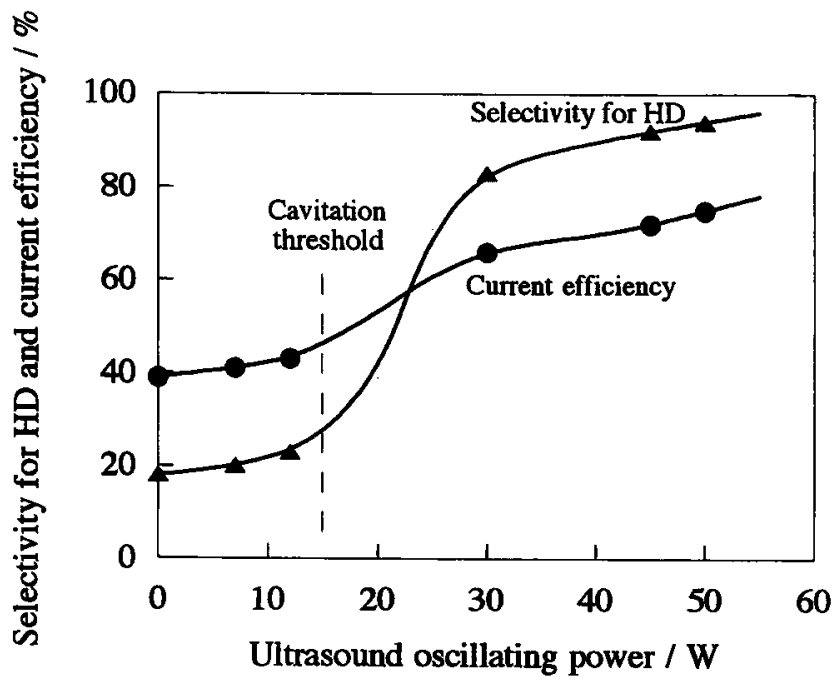

Fig. 13 Dependence of ultrasound oscillating power on product selectivity (HD/HM) ( $\mathbf{A})$ and current efficiency (O) in the reduction of $p$-methylbenzaldehyde.

示度との関係であり，この場合はキャビテーションが出力 15 W(しきい值)以上で生起することを示している．むちろん，2.1 の記述からむ自明のように, キャビテーションしきい值は電解装 专の幾何学的形状に依存するが，溶液粘度等の電解液の物理的性 状にも強く倲存する。

一方，上述の電解系にお污る物質移動速度の指標である限界電 流密度 $\left(i_{\mathrm{L}}\right)$ との成釈は Fig. 12 に示されるか， $i_{\mathrm{L}}$ 增加の臨界超音

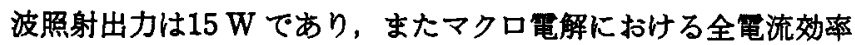
$(\mathrm{HD}+\mathrm{HM})$ さらには HD 生成選択率むこの15 W のキャビテー ションしきい值を境に急增することが明らかとなった(Fig. 13). つまり，物質移動速度の增加すなわち著しい超音波効果は，キャ ビテーションしきい值以下における単なる音場効果だけでは生起 せず, キャビテーションによるシェット流の発生が必須条件であ ることが確証された。

\section{6 電解重合反応への応用}

電解重合は電解開始重合と電解酸化・罯元重合に大別される. 電解開始重合で恃重合開始剂が電解反応に上って生成され，重合 反応自体は化学重合と本質的には同しである．したがって，超音 波奻果む電解重合に独特なるのではな(53)54).

一方，電解酸化・還元重合ではモノマーが酸化または還元され
つつ重合が進行し，電気化学量論量の通電量を要するので電解開 始重合とは全く異なる特異な超音波効果が期待される。とく芳 香族化合物の電解酸化重合膜は電気伝導性, レドックス性, ドー ピング性，光電応答性，半導体性，エレクトロクロミック性など 多様な有用特性をもち，すでに多くの実用用途の開拓がなされて いる. しかし，超音波効果利用の事例は極好少ない(55)56)，

著者らは電位鲛引法によるアニリンの電解酸化重合をモデ反 応(Scheme 10)とし，超音波の作用効果を検討した，その結果， 超音波照射によりアニリン重合膜の表面平滑性が著しく改善され ることが明らかとなった(Fig. 14)57).

また，超音波照射により得られるアニリン重合膜は極めてち密 でしかも酸化・還元の綝り返しに対する安定性も示され(Table 7)，実用展開への期待が高まっている.
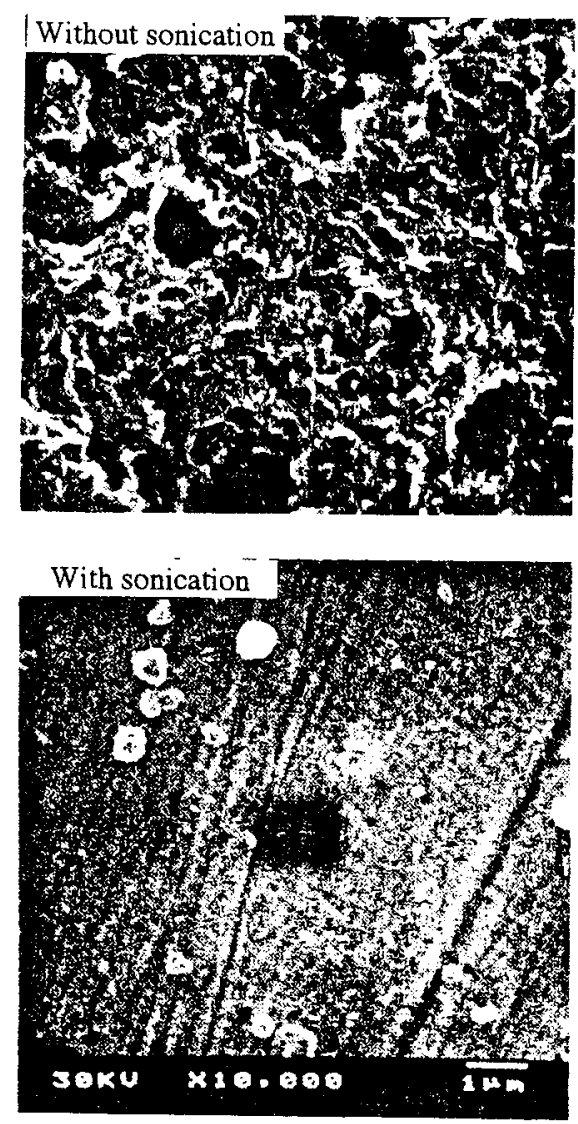

Fig. 14 SEM photographs of polyaniline films prepared at 50 times of potential scanning without and with sonication.<smiles>CC(C)(C)Nc1ccc(Nc2ccc(Nc3ccc(NC(C)(C)C)cc3)cc2)cc1</smiles>

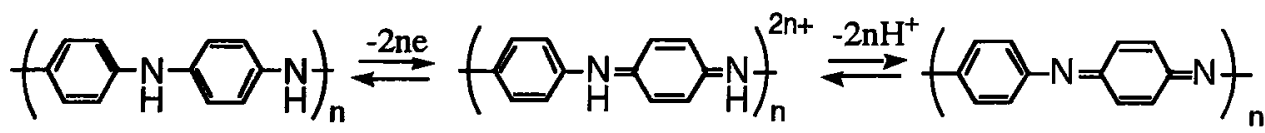

Scheme 10 Electrooxidative polymerization of aniline and doping/dedoping of the polyaniline. 
Table 7 Properties of polyaniline films prepared without and with sonication

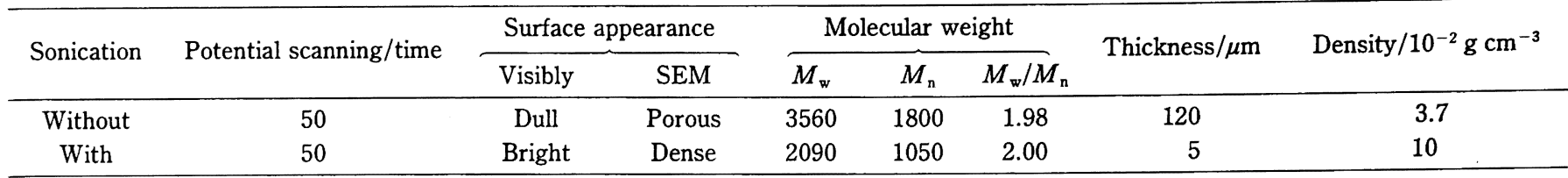

さらに，自己組織化吸着と超音波の巧妙な組み合わせ効果によ り，無欠陥単分子膜の形成が実証され，超分子機能膜として注目 されている58).

\section{7 おわりに}

化学分野に扮ける超音波利用技術はキャビテーション現象に代 表される原理的側面の特異性からみて，他をむって代替できない 要素を多分に含んでおり，化学過程の制御のための方法論として 極めて魅力的である，それにもかかわらず，技術としての発達 度，利用度のいずれに拈いても未熟な点が多い。このことは今 後, さらなる発展のための潜在力と余地が極めて大きいともい え，本論文において述べた有機電極反応への超音波利用は広範な 化学分野における一例を示したにすぎない，幸いにして，超音波 電気化学(ソノエレクトロケミストリー)はもとより技術の基盤と なる超音波化学(ソノケミストリー)の近年の発展には目覚ましい むのがあり，応用展開に向け満を持しているところである. 化学 反応に打ける超音波効果の先駆的研究は60 年以上前に日本で開 始された，応用技術の開拓のリーダーも我が国が任ずることを念 じたい.

本研究を遂行するにあたり次の方々からの実験の分担協力, ま た，有益な議論，助言など様々な形で御協力をいただい: 淵上 寿雄, 昆野昭則, 上羽貞行, 小池義和, 榎本尚也, 佐藤尚武, 松 田和也, 望月詳子, 不破誠二, 角 佳典, 佐藤和长, 藤原 宗, 殿井貴之, 鏑木武志の各氏. 記して深く感謝の意を表す. また, 本研究は次の文部省科学研究費補助金による助成を受けた：重点 領域研究「有機電気化学」「特殊反応場触媒」および「構造規制 電極」.

1) R. W. Wood, A. L. Loomis, Phil. Mag., 4, 414(1927).

2）森口信男, 日化, 54, 949(1933).

3）森口信男, 日化, 55, 749(1934).

4）森口信男, 日化, $\mathbf{5 5}, 751(1934)$.

5) T. J. Mason, "Sonochemistry", The Royal Society of Chemistry, Cambridge (1990).

6) T. J. Mason, "Chemistry with Ultrasound", The Society of Chemical Industry, Essex (1990).

7) T. J. Mason, "Advances in Sonochemistry Volume 1", JAI Press LTD, Connecticat (1990).

8) T. J. Mason, "Advances in Sonochemistry Volume 2", JAI Press LTD, Connecticat (1991).

9) T. J. Mason, "Advances in Sonochemistry Volume 3", JAI Press LTD, Connecticat (1993).

10) G. T. Price, "Current Trend in Sonochemistry", The Society of Chemical Industry, Cambridge (1992).

11) T. J. Mason, J. P. Lorimer, D. J. Walton, Ultrasonics, 28, 333(1990).

12) R. Walker, Chem. Britain, 26, 251(1990).

13) B. A. Shenoi, K. S. Indira, R. Subramanian, Met. Finish., 68, 57 (1970).
14) D. J. Walton, S. S. Phull, "Advances in Sonochemistry Vol. 4”, ed by T. J. Mason, JAI Press LTD, Connecticat (1996), pp. 205-284.

15）野中 勉, 跡部真人, 化学工業, 47, 615(1996).

16）辰本伸英, 藤井茂忠, 野中 勉, 超音波テクノ，9[7], 18 (1997).

17）跡部真人，電気化学， 65, 560(1997).

18) A. Benahcene, C. Petrier, G. Reverdy, New J. Chem., 19, 989(1995).

19) K. Matsuda, M. Atobe, T. Nonaka, Chem. Lett., 1994, 1619.

20）森田克美，“超音波洗浄”，近代編集社(1989).

21) M. Atobe, T. Nonaka, Chem. Lett., 1995, 669.

22) M. Atobe, T. Nonaka, J. Electroanal. Chem., 425, 161 (1997).

23) V. Yegnaraman, S. Bharathi, Bull. Electrochem., 8, 84 (1992).

24) C. R. S. Hagan, L. A. Coury, Jr., Anal. Chem., 66, 399 (1994).

25) R. G. Compton, J. C. Eklund, S. D. Page, J. Phys. Chem., 99, 4211(1995).

26) D. J. Walton, S. S. Phull, A. Chyla, J. P. Lorimer, T. J. Mason, L. D. Barke, M. Murphy, R. G. Compton, J. C. Eklund, S. D. Page, J. Appl. Electrochem., 25, 1083(1995).

27) J. Reisse, H. Francois, J. Vandercammen, O. Fabre, A. K. Mesmaeker, C. Maerschalk, J.-L. Delplancke, Electrochim. Acta, 39, 37(1994).

28) P. R. Birkin, S. S. Martinez, J. Chem. Soc., Chem. Commun., 1995, 1807.

29) H. D. Dewald, B. A. Peterson, Anal. Chem., 62, 779 (1990).

30) M. Atobe, K. Matsuda, T. Nonaka, Electroanalysis, 8, 784 (1996).

31) P.-C. Cheng, T. Nonaka, J. Electroanal. Chem., 269, 223 (1989).

32) P.-C. Cheng, T. Nonaka, T.-C. Chou, Bull. Chem. Soc. Jpn., 64, 1911(1991).

33) P.-C. Cheng, T. Nonaka, Bull. Chem. Soc. Jpn., 64, 3500 (1991).

34) P.-C. Chen, T. Nonaka, Denki Kagaku, 62, 131 (1992).

35) P.-C. Chen, T. Nonaka, Bull. Chem. Soc. Jpn., 68, 378 (1995).

36) J. Chaussard, M. Troupel, Y. Bobin, G. Jacob, J. P. Jukasz, J. Appl. Electrochem., 19, 345(1989).

37) G. E. Braithwait, U. S. Patent 3391067(1968).

38) M. Atobe, K. Matsuda, T. Nonaka, Denki Kagaku, 62, 1298(1994).

39) M. Atobe, T. Nonaka, Bull. Chem. Soc. Jpn., 71, 397 (1998).

40) M. Fleishmann, G. Mengoli, D. Pletcher, Electrochim. Acta, 18, 231 (1973).

41) H. E. Ulery, J. Electrochem. Soc., 120, 1493(1973).

42) H. E. Ulery, J. Electrochem. Soc., 119, 1474(1972).

43) O. R. Brown, E. R. Gonzalez, A. R. Wright, Electrochim. Acta, 18, 369 (1973).

44) H. E. Ulery, J. Electrochem. Soc., 116, 1201(1969).

45) M. Atobe, T. Nonaka, Ultrasonics Sonochem., 4, 17(1997).

46) 野中 勉, 杉野喜一郎, 電気化学, 34, 105(1966). 
47) M. Atobe, T. Nonaka, Ultrasonics World Congress, Extended Abstracts, p. 140(1997).

48) M. Atobe, Y. Kado, T. Nonaka, The 3rd International Symposium on Electroorganic Synthesis, Extended Abstracts, p. 144(1997).

49) J. Klima, C. Bernard, C. Degrand, J. Electroanal. Chem., 367, 297(1994).

50) J. Klima, C. Bernard, C. Degrand, J. Electroanal. Chem., 399, 147(1995).

51) M. Atobe, T. Nonaka, 189th Electrochem. Soc. Meet., Extended Abstracts, No. 1007 (1996).

52) M. Atobe, T. Nonaka, Chem. Lett., 1997, 323.
53) U. Akbulut, L. Toppare, B. Yurttas, Polymer, 27, 803 (1986).

54) S. P. Aybar, B. Hacioglu, U. Akbulut, J. Polym. Sci., 29, 1971 (1991).

55) S. Osawa, M. Ito, K. Tanaka, J. Kuwano, Synth. Met., 18, 145(1987).

56) S. Osawa, M. Ito, K. Tanaka, J. Kuwano, Polym. Phys., 30, 19(1992).

57) M. Atobe, S. Fuwa, N. Sato, T. Nonaka, Denki Kagaku, 65, 495(1997).

58) N. Sato, T. Nonaka, Chem. Lett., 1995, 805.

\title{
New Developments of Sonoelectrochemistry - Electroorganic Reactions under Ultrasonic Fields - \\ Mahito ATOBE and Tsutomu NONAKA* \\ Department of Electronic Chemistry, Tokyo Institute of Technology; 4259 Nagatsuta, Midori-ku, Yokohama-shi 226-8502 Japan
}

\begin{abstract}
Effects of ultrasounds on electroorganic processes have extensively been examined in a series of investigations. The current efficiency and/or product selectivity were found to be greatly affected by ultrasonic irradiation. From experimental and theoretical considerations, it was verified that the effects are caused by mass transport enhanced by ultrasonic cavitation in the electrode interface. In addition, highly dense and uniform polymer films could be prepared by electrooxidative polymerization under ultrasonic irradiation. As a conclusion, it is stated that ultrasounds offer a powerful and useful method for purposive reaction control in a variety of electroorganic processes.
\end{abstract}

